\title{
Effect of oxygenation modalities among patients with postoperative respiratory failure: a pairwise and network meta- analysis of randomized controlled trials
}

Yazan Zayed ${ }^{1 *}$ (D, Babikir Kheiri ${ }^{2}$, Mahmoud Barbarawi ${ }^{1}$, Laith Rashdan', Inderdeep Gakhal', Esra'a Ismail ${ }^{3}$, Josiane Kerbage ${ }^{4}$, Fatima Rizk ${ }^{5}$, Saadia Shafi ${ }^{1}$, Areeg Bala', Shima Sidahmed', Ghassan Bachuwa ${ }^{1}$ and Elfateh Seedahmed ${ }^{6}$

\begin{abstract}
Background: Postoperative respiratory failure is associated with increased perioperative complications. Our aim is to compare outcomes between non-invasive ventilation (NIV), high-flow nasal cannula (HFNC), and standard oxygen in patients at high-risk for or with established postoperative respiratory failure.

Methods: Electronic databases including PubMed, Embase, and the Cochrane Library were reviewed from inception to September 2019. We included only randomized controlled trials (RCTs) that compared NIV, HFNC, and standard oxygen in patients at high risk for or with established postoperative respiratory failure. We performed a Bayesian network meta-analysis to calculate the odds ratio (OR) and Bayesian 95\% credible intervals (Crls).

Results: Nine RCTs representing 1865 patients were included (the mean age was $61.6 \pm 10.2$ and $64.4 \%$ were males). In comparison with standard oxygen, NIV was associated with a significant reduction in intubation rate (OR 0.23; 95\% Cr.l. 0.10-0.46), mortality (OR 0.45; 95\% Cr.I. 0.27-0.71), and intensive care unit (ICU)-acquired infections (OR 0.43, 95\% Cr.l. 0.25-0.70). Compared to standard oxygen, HFNC was associated with a significant reduction in intubation rate (OR 0.28, 95\% Cr.I. 0.08-0.76) and ICU-acquired infections (OR 0.41; 95\% Cr.I. 0.20-0.80), but not mortality (OR 0.58; 95\% Cr.I. 0.26-1.22). There were no significant differences between HFNC and NIV regarding different outcomes. In a subgroup analysis, we observed a mortality benefit with NIV over standard oxygen in patients undergoing cardiothoracic surgeries but not in abdominal surgeries. Furthermore, in comparison with standard oxygen, NIV and HFNC were associated with lower intubation rates following cardiothoracic surgeries while only NIV reduced the intubation rates following abdominal surgeries.
\end{abstract}

Conclusions: Among patients with post-operative respiratory failure, HFNC and NIV were associated with significantly reduced rates of intubation and ICU-acquired infections compared with standard oxygen. Moreover, NIV was associated with reduced mortality in comparison with standard oxygen.

Keywords: Postoperative respiratory failure, High-flow nasal cannula, Non-invasive ventilation, Standard oxygen, Meta-analysis

\footnotetext{
*Correspondence: yzayed1@hurleymc.com; yz.alzayed@yahoo.com

'Department of Internal Medicine, Hurley Medical Center/Michigan State University, One Hurley Plaza, Suite 212, Flint, Ml 48503, USA

Full list of author information is available at the end of the article
} 


\section{Introduction}

Postoperative respiratory failure is associated with increased perioperative complications such as reintubation, invasive mechanical ventilation, and healthcareassociated infections, which can lead to increases in mortality, intensive care unit (ICU) and hospital length of stay, delays in hospital discharges, and higher healthcare resource utilization [1-4].

Several post-operative pulmonary complications may result in post-operative hypoxemic respiratory failure, including pneumonia, atelectasis, bronchospasm, pneumothorax, and pleural effusion. The incidence of these complications is variable and ranges between 5 and $40 \%$ according to the type of surgery, as well as other risk factors including anesthetic technique, duration of surgery, and severity of illness [5-9]. Cardiac surgery has the highest rate of post-operative respiratory complications (up to 40\%), followed by thoracic surgery (30\%), while abdominal and vascular surgeries have a low incidence of post-operative pulmonary complications $(6-7 \%)$ [5-7].

In nonsurgical patients, oxygenation modalities for hypoxemic respiratory failure are varied. Non-invasive ventilation (NIV) has shown promising results for reducing intubation rates among patients with cardiogenic pulmonary edema and chronic obstructive pulmonary disease exacerbations [10-12]. High-flow nasal cannula (HFNC) is a new oxygenation strategy that delivers oxygen at high concentrations and a high flow rate and has been increasingly utilized due to its ease of application, tolerance, and potential clinical benefits [13, 14]. Nevertheless, the current European Respiratory Society/ American Thoracic Society (ERS/ATS) guidelines have conditional recommendations regarding the use of NIV in postoperative respiratory failure [15]. In addition, few randomized controlled trials (RCTs) have been conducted to evaluate the efficacy of HFNC vs NIV in postoperative patients. Therefore, we conducted a metaanalysis to compare the efficacy and safety of HFNC, NIV, and standard oxygen therapy in the treatment of patients who developed or were considered high risk for post-operative respiratory failure.

\section{Methodology}

\section{Study design and study selection}

Our study is a meta-analysis and systematic review performed according to the Preferred Reporting Items for Systematic Reviews and Meta-Analyses Protocols (PRIS MA-P) 2015 Statement [16]. Two reviewers (M.B., I.G) independently and separately performed a literature search utilizing electronic databases including PubMed, Cochrane Library, and Embase from inception to September 2019 without language restrictions. Articles were first screened by titles and abstracts before exclusion.
Full texts of eligible articles were reviewed for final inclusion or exclusion. Mesh terms used were as follows: "postoperative respiratory failure", "respiratory failure", "postoperative", "hypoxemic", "hypoxic", "non-invasive ventilation", "NIV", "high-flow nasal cannula", "HFNC", "high-flow nasal therapy", "HFNT", "high-flow nasal oxygen", "HFNO", “oxygen", "facemask", and "ventilation". References of relevant articles were also reviewed for possible inclusion. A third reviewer (YZ) resolved any discrepancies.

\section{Inclusion criteria and study selection}

Only RCTs were eligible for inclusion in our analysis. We included studies that compared different oxygenation strategies in patients who developed or were deemed at high risk for developing post-operative hypoxemic respiratory failure. Patients at risk were defined to have intermediate to high risk for development of post-operative pulmonary complications according to either Assess Respiratory Risk in Surgical Patients in Catalonia (ARISCAT) score of $\geq 26$ points [4]. Patients who failed spontaneous breathing trial and those who passed spontaneous breathing trials but had risk factors for failed extubation such as cardiac dysfunction, obesity (BMI > 30), or failure of previous extubation were also considered high risk. Post-operative hypoxemic respiratory failure was defined as the development of tachypnea with a respiratory rate of $\geq 25$ respirations per minute, intense work of breathing with the use of accessory muscles, hypoxemia (oxygen saturation $\leq 92 \%$ or partial arterial oxygen pressure to fraction of inspired oxygen $\leq$ 300) in the immediate post-operative period or within 7 days post-operatively. We excluded studies that investigated prophylactic use of NIV and HFNC as a routine therapy in the post-operative period.

Data were extracted into a predesigned table independently and separately by two reviewers (L.R and S.S.). Any discrepancies were solved by consensus with a third reviewer (Y.Z.).

\section{Quality assessment}

Cochrane Collaboration's tool for assessing risk of bias in randomized controlled trials was used for quality assessment for the included RCTs [17]. Each of the included RCTs was assessed for random sequence generation, allocation concealment, blindness of participants and health-care personnel, blindness of outcome assessment, incomplete outcome data, selective reporting, and other biases if any were present.

\section{Outcomes}

Our main outcome was the intubation rate following surgery. Secondary outcomes included mortality at the 
longest follow-up period provided by each study and ICU-acquired infections.

\section{Statistical analysis}

An informative prior Bayesian framework for the network meta-analysis was performed using the Markov Chain Monte Carlo simulation to derive the posterior distribution of the parameter estimates. We used a beta distribution of $(0,2)$ for binominal likelihood. We used the Brooks-Gelman-Rubin method to assess for convergence. A consistency model which contains treatment as a fixed effect and trial as a random effect was used. Results were reported as odds ratios (ORs) and Bayesian 95\% credible intervals (Cr.Is). Inconsistency was assessed using the deviance residuals and deviance information criteria statistics. Sensitivity analysis was performed by including only trials that included patients who had developed respiratory failure. Furthermore, subgroup analysis according to the type of surgery (cardiothoracic or abdominal) was performed. In addition, to show the validity of our results, we performed a direct pairwise meta-analysis for comparisons that have three or more studies comparing directly the two interventions.
In an exploratory analysis, we performed a metaregression analysis to explain any significant heterogeneity (> 25\%) for NIV vs standard oxygen therapy direct meta-analysis. Moderators included study-level covariates: age, gender, body mass index, Simplified Acute Physiology Score (SAPS) II, respiratory rate, $\mathrm{PaO} 2 / \mathrm{FiO} 2$ ratio, and partial arterial pressure of carbon dioxide (PaCO2). All data were analyzed using RevMan v5.3 Windows, Comprehensive Meta-Analysis software v3, NetMetaXL v1.6.1, and WinBUGS v1.4.3.

\section{Results}

\section{Summary of the included studies}

After review of 1369 articles, 9 studies were included in the final analysis representing 1865 patients [18-26]. Figure 1 illustrates the search process. The mean age was $61.6 \pm 10.2$, and $64.4 \%$ were males. Four RCTs included patients undergoing cardiac and/or lung surgeries [19, 20, 24, 26], 3 RCTs involved patients undergoing abdominal surgeries [21-23], and 2 RCTs included patients following organ transplantation [18, 25]. Two trials included patients considered at high risk of post-operative pulmonary complications and respiratory failure [23, 26] and one trial included patients at risk for respiratory

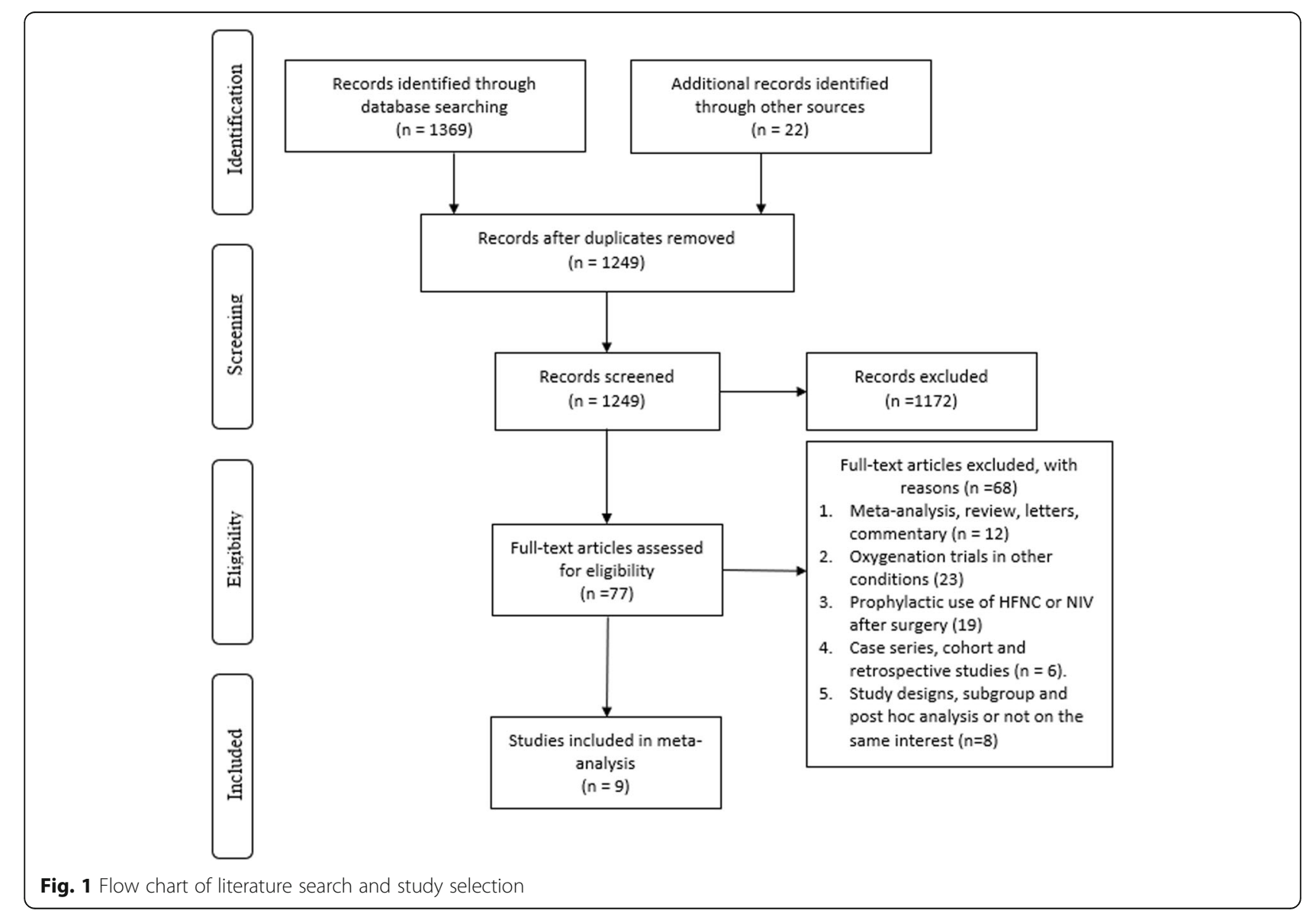


failure or patients with established respiratory failure [20] while six trials included patients who developed respiratory failure in the immediate post-operative period or up to 7 days postoperatively [18, 19, 21, 22, 24, 25]. Two trials compared HFNC vs NIV [18, 20], five trials compared NIV vs standard oxygen therapy [19, 21, 22, $24,25]$, and 2 trials compared HFNC vs standard oxygen therapy [23, 26]. Table 1 explains the characteristics of the included trials, and Supplementary Figure 1 illustrates the network geometry. NIV was the most commonly used treatment (41.2\% of patients), HFNC was used in $31.6 \%$ of cases, and $27.2 \%$ of patients were treated with standard oxygen therapy. Table 2 explains the baseline and demographic characteristics of included patients.

Included studies were noted to have inevitable performance bias as blinding of participants and personnel was difficult given the nature of the intervention. Detailed quality assessment was not performed for one study as we only found the abstract with no full article explaining the methods. Supplementary Figure 2 shows the risk of bias in each included RCT based on the authors' judgment.

\section{Outcomes}

\section{Rate of intubation}

NIV and HFNC were associated with significant reductions in intubation rates when compared to standard oxygen therapy (OR 0.23 ; $95 \%$ Cr.I. $0.10-0.46)$ and (OR 0.28; 95\% Cr.I. 0.08-0.76), respectively. However, there was no significant difference between HFNC and NIV with regard to the intubation rates (OR 0.82; 95\% Cr.I. 0.30-2.50), Fig. 2.

Sensitivity analysis was performed by including only patients who developed acute hypoxemic respiratory failure (but not patients at increased risk), which showed similar results. In a subgroup analysis for patients undergoing cardiothoracic surgery, both NIV and HFNC were associated with a similar reduction in intubation rates compared with standard oxygen therapy (NIV vs standard oxygen (OR 0.08 ; 95\% Cr.I. 0.03-0.19) and HFN vs standard oxygen (OR 0.08; 95\% Cr.I. 0.03-0.21)) (Fig. 3a). However, in patients undergoing abdominal surgery, NIV (but not HFNC) was associated with significantly reduced intubation rates compared with standard therapy (NIV vs standard oxygen (OR 0.51; 95\% Cr.I. 0.26-0.87)) (Fig. 3b).

In an exploratory meta-regression analysis, we found that higher $\mathrm{PaCO} 2$ was associated with lower risk for intubation when NIV was compared to standard oxygen therapy $(P<0.05)$ (Supplementary Figure 3$)$.

\section{Mortality}

NIV was associated with a significant reduction of mortality in comparison with standard oxygen therapy (OR
0.45; 95\% Cr.I. 0.27-0.71). Additionally, there was no significant difference between NIV and HFNC (OR 0.78; 95\% Cr.I. 0.41-1.50) or HFNC and standard oxygen (OR 0.58; 95\% Cr.I. 0.26-1.22) as shown in Fig. 4.

In a subgroup analysis based on the type of surgery (cardiothoracic or abdominal), mortality benefit of NIV was limited to those undergoing cardiothoracic surgery compared with standard oxygen therapy (OR 0.31; 95\% Cr.I. 0.13-0.70), unlike those undergoing abdominal surgeries (OR 0.56; 95\% Cr.I. 0.27-1.08) (Fig. 5).

\section{ICU-acquired infections}

HFNC and NIV were associated with a decreased risk for ICU-acquired infections in comparison with standard oxygen therapy (OR 0.41; 95\% Cr.I. 0.20-0.80) and (OR 0.43 ; $95 \%$ Cr.I. $0.25-0.70$ ), respectively. No significant difference was found between HFNC and NIV (Fig. 6).

\section{Direct pairwise meta-analysis results}

We have performed direct pairwise meta-analysis comparing NIV versus standard oxygen which showed consistent results of the network meta-analysis (Supplementary Figure 4). However, we did not perform the direct meta-analysis for HFNC vs NIV or HFNC vs standard oxygen because studies that compared directly between these interventions were one or two studies. Supplementary Figures 5 and 6 show the results of these individual studies for different outcomes.

\section{Discussion}

In this first network meta-analysis comparing various oxygenation strategies in patients at risk for hypoxemic respiratory failure or established respiratory failure within 7 days of surgery, we have found that NIV and HFNC were associated with a significant reduction in intubation rates and ICU-acquired infections when compared to standard oxygen therapy. However, when compared to standard oxygen therapy, only NIV was found to have a mortality benefit in this patient population. We found HFNC and NIV to have no significant differences in the primary or secondary outcomes. Furthermore, in a subgroup analysis, patients undergoing cardiothoracic surgery had a significantly lower rate of intubation when treated with HFNC or NIV in comparison with standard oxygen therapy, but mortality was significantly lower in patients treated with NIV in comparison with standard oxygen therapy. Additionally, in patients with abdominal surgeries, only NIV was associated with a significant reduction in intubation rates compared to standard oxygen, but there was no significant difference in mortality between competing interventions.

Hypoxemia occurs frequently in the post-operative period and can lead to acute respiratory failure. Several 
Table 1 Characteristics of the included studies

\begin{tabular}{|c|c|c|c|c|c|}
\hline $\begin{array}{l}\text { Study } \\
\text { (author, } \\
\text { year) }\end{array}$ & $\begin{array}{l}\text { Study } \\
\text { groups }\end{array}$ & Study design & Inclusion criteria & $\begin{array}{l}\text { Settings of experimental group and } \\
\text { control group intervention }\end{array}$ & $\begin{array}{l}\text { Follow-up } \\
\text { period }\end{array}$ \\
\hline Yu, 2017 & $\begin{array}{l}\text { HFNC } \\
56, \mathrm{SO} \\
54\end{array}$ & $\begin{array}{l}\text { Multicenter, prospective, randomize, interventional } \\
\text { trial }\end{array}$ & $\begin{array}{l}\text { Patients who underwent thoracoscopic } \\
\text { lobectomy because of lung tumor and } \\
\text { were at intermediate to high risk for } \\
\text { PPC as determined by an ARISCAT } \\
\text { score } \geq 26 \text {. Patients were } \\
\text { immunocompetent, not pregnant, } \\
\text { between } 18 \text { and } 80 \text { years old }\end{array}$ & $\begin{array}{l}\text { HFNC: received at a flow rate if } 35 \text { to } \\
60 \mathrm{~L} / \mathrm{min} \text { and } \mathrm{FiO} 2 \text { was titrated from } 45 \\
\text { to } 100 \% \text { to maintain a } \mathrm{SpO} 2 \text { of } 95 \% \text { or } \\
\text { more } \\
\text { SO: received oxygen via nasal prongs } \\
\text { or facemasks with } \mathrm{FiO} 2 \text { titrated } \\
\text { between } 45 \text { and } 100 \% \text { to maintain } \\
\text { SpO2 of } 95 \% \text { or more }\end{array}$ & $\begin{array}{l}72 \mathrm{~h} \\
\text { following } \\
\text { extubation }\end{array}$ \\
\hline Futier, 2016 & $\begin{array}{l}\text { HFNC } \\
108 \\
\text { SO } \\
112\end{array}$ & Multicenter, randomized controlled trial & $\begin{array}{l}\text { Adult patients scheduled for planned } \\
\text { or unplanned abdominal, or abdominal } \\
\text { and thoracic surgery with and } \\
\text { anticipated duration of } 2 \mathrm{~h} \text { or more } \\
\text { and an ARISCAT score } \geq 26\end{array}$ & $\begin{array}{l}\text { HFNC: flow rate of } 50 \text { to } 60 \mathrm{~L} / \mathrm{min} \text { to } \\
\text { maintain an } \mathrm{SpO} 2 \text { of } 95 \% \text { or more } \\
\text { SO: O2 delivered continuously using } \\
\text { nasal prongs or facemasks to maintain } \\
\text { an SpO2 of } 95 \% \text { or more }\end{array}$ & $\begin{array}{l}7 \text { days } \\
\text { post-op }\end{array}$ \\
\hline Gupta, 2016 & $\begin{array}{l}\text { HFNC } \\
10, \text { NIV } \\
10\end{array}$ & $\begin{array}{l}\text { Pilot study, single-center, randomized controlled } \\
\text { trial }\end{array}$ & $\begin{array}{l}\text { Postoperative hypoxemia in post-liver } \\
\text { transplant patients }\end{array}$ & $\begin{array}{l}\text { HFNC: initiated at a flow rate of } 60 \mathrm{~L} / \\
\text { min and titrated according to } A B G \\
\text { NIV: set EPAP of } 5 \mathrm{~cm} \text { and IPAP at } 10 \\
\mathrm{~cm} \text { and titrated according to ABG }\end{array}$ & $\begin{array}{l}48 \mathrm{~h} \text { post- } \\
\text { op. }\end{array}$ \\
\hline Jaber, 2016 & $\begin{array}{l}\text { SO } \\
145 \\
\text { NIV } \\
148\end{array}$ & Multicenter, randomized, parallel-group clinical trial & $\begin{array}{l}\text { Patients older than } 19 \text { who had } \\
\text { undergone laparoscopic or non- } \\
\text { laparoscopic elective or nonelective ab- } \\
\text { dominal surgery under general } \\
\text { anesthesia that were diagnosed with } \\
\text { ARF within } 7 \text { days of surgical procedure } \\
\text { defined as persistence of more than } \\
30 \text { min of hypoxemia }\end{array}$ & $\begin{array}{l}\text { SO: supplemental } \mathrm{O} 2 \text { at a rate of up to } \\
15 \mathrm{~L} / \mathrm{min} \text { to maintain } \mathrm{SpO} 2 \text { of at least } \\
94 \% \\
\mathrm{NIV} \text { : facemask connected to an ICU or } \\
\text { NIV dedicated ventilator titrating PEEP } \\
\text { and } \mathrm{FiO} 2 \text { to maintain an SpO2 of at } \\
\text { least } 94 \%\end{array}$ & $\begin{array}{l}90 \text { days } \\
\text { post-op. }\end{array}$ \\
\hline $\begin{array}{l}\text { Stephan, } \\
2015\end{array}$ & $\begin{array}{l}\text { HFNC } \\
414, \\
\text { NIV } \\
416\end{array}$ & Multicenter, randomized, noninferiority trial & $\begin{array}{l}\text { Patients who had undergone } \\
\text { cardiothoracic surgery who developed } \\
\text { ARF (failure of SBT or successful SBT } \\
\text { but failed extubation) or were deemed } \\
\text { at risk for respiratory failure post- } \\
\text { extubation due to preexisting risk } \\
\text { factors }\end{array}$ & $\begin{array}{l}\text { HFNC: initial rate of } 50 \mathrm{~L} / \mathrm{min} \text { with initial } \\
\mathrm{FiO} 250 \% \text { adjusted to maintain } \mathrm{SpO} 2 \\
92 \% \text { or more } \\
\text { BiPAP: full facemask connected to } \\
\text { ventilator with adjustments made to } \\
\text { PEEP and FiO2 to maintain } \mathrm{SpO} 2 \text { of } \\
92 \% \text { or more }\end{array}$ & 3 days \\
\hline Zhu, 2013 & $\begin{array}{l}\text { NIV } 48 \\
\text { SO } 47\end{array}$ & $\begin{array}{l}\text { Single-center, prospective, randomized control } \\
\text { study }\end{array}$ & $\begin{array}{l}\text { Patients who after cardiac surgery } \\
\text { developed ARF after initial extubation } \\
\text { who were hemodynamically stable } \\
\text { with no evidence of bleeding }\end{array}$ & $\begin{array}{l}\text { NPPV: BiPAP via facemask. FiO2 } \\
\text { adjusted to maintain SpO2 of around } \\
92 \% \\
\text { SO: standard medical care and oxygen } \\
\text { therapy as needed }\end{array}$ & $\begin{array}{l}\text { Length of } \\
\text { hospital } \\
\text { stay }\end{array}$ \\
\hline $\begin{array}{l}\text { Squadrone, } \\
2005\end{array}$ & $\begin{array}{l}\text { NIV } \\
105 \\
\text { SO } \\
104\end{array}$ & $\begin{array}{l}\text { Multicenter, randomized, controlled, unblinded } \\
\text { study }\end{array}$ & $\begin{array}{l}\text { Post-op elective abdominal surgery } \\
\text { under GA if surgery required } \\
\text { laparotomy and time of viscera } \\
\text { exposure longer than } 90 \text { min. Patients } \\
\text { were extubated after surgery, and if } \\
\text { they developed a PaO2/FiO2 of } 300 \\
\text { less, they were included in study. }\end{array}$ & $\begin{array}{l}\text { CPAP: treated with } \mathrm{FiO} 2 \text { of } 0.5 \text { plus } \\
\text { CPAP of } 7.5 \text {. After } 6 \text { h, patients } \\
\text { underwent } 1 \text { - } \mathrm{h} \text { screening test breathing } \\
\mathrm{O} 2 \text { through a venture mask at an } \mathrm{FiO} 2 \\
\text { of } 0.3 \text {. Patients returned to assigned } \\
\text { treatment if } \mathrm{PaO} 2 / \mathrm{FiO} 2 \text { ratio was } 300 \text { or } \\
\text { less, and treatment was interrupted if } \\
\text { the ratio was higher than } 300 \\
\mathrm{SO}: 8 \text { to } 10 \mathrm{~L} / \text { min oxygen. }\end{array}$ & $\begin{array}{l}\text { Length of } \\
\text { hospital } \\
\text { stay }\end{array}$ \\
\hline $\begin{array}{l}\text { Auriant, } \\
2001\end{array}$ & $\begin{array}{l}\text { NIV } 24 \\
\text { SO } 24\end{array}$ & Prospective, randomized controlled trial & $\begin{array}{l}\text { Patients with AHRI following lung } \\
\text { resection if they met at least three of } \\
\text { the following criteria: dyspnea at rest, } \\
\text { active contraction of accessory } \\
\text { respiratory muscles, } \mathrm{PaO} 2 / \mathrm{FiO} 2 \text { less } \\
\text { than } 200 \text {, chest radiographic } \\
\text { abnormalities }\end{array}$ & $\begin{array}{l}\text { NPPV: cushion bridge nasal mask with } \\
\text { BiPAP. PS was increased to achieve } \\
\text { exhaled TV of } 8-10 \mathrm{~mL} / \mathrm{kg} \text { and RR of } \\
\text { less than } 25 \text { breaths } / \mathrm{min} \text {. FiO2 was } \\
\text { adjusted to obtain } \mathrm{SpO} 2 \text { above } 90 \% \\
\text { SO: O2 supplementation to achieve } \\
\mathrm{SaO} 2 \text { above } 90 \%\end{array}$ & 120 days \\
\hline $\begin{array}{l}\text { Antonelli, } \\
2000\end{array}$ & $\begin{array}{l}\text { NIV 20, } \\
\text { SO } 20\end{array}$ & Single center, prospective, randomized study & $\begin{array}{l}\text { Recipients of solid organ transplants } \\
\text { with acute hypoxemic respiratory } \\
\text { failure. Criteria included acute } \\
\text { respiratory distress, respiratory rate } \\
\text { greater than } 35 / \mathrm{min} \text {, ratio of } \mathrm{PaO} 2 / \\
\mathrm{FiO} 2 \text { of less than } 200 \text {, active } \\
\text { contraction of accessory muscles or } \\
\text { paradoxical abdominal motion }\end{array}$ & $\begin{array}{l}\text { NIV: ventilator connected to full-face } \\
\text { mask with titration of PS to obtain ex- } \\
\text { haled TV of } 8 \text { to } 10 \mathrm{~mL} / \mathrm{kg} \text {, RR less than } \\
25 / \mathrm{min} \text {. PEEP increased gradually and } \\
\text { up to } 10 \mathrm{~cm} \mathrm{H}_{2} \mathrm{O} \text { until FiO2 require- } \\
\text { ment was } 0.6 \text { or less. Settings were ad- } \\
\text { justed based on continuous oximetry } \\
\text { and measurements of ABG. } \\
\text { Standard oxygen: Venturi mask started } \\
\text { with FiO2 of } 40 \% \text { and titrated to } \\
\text { achieve a level of SpO2 } 90 \%\end{array}$ & NA \\
\hline
\end{tabular}

HFNC high-flow nasal cannula, SO standard oxygen, NIV non-invasive ventilation, $P P C$ postoperative pulmonary complications, ARISCAT assess respiratory risk in surgical patients in Catalonia, FiO2 fraction of inspired oxygen, SpO2 peripheral capillary oxygen saturation, $L$ liters, min minute, $A B G$ arterial blood gas, EPAP expiratory positive airway pressure, IPAP inspiratory positive airway pressure, $A R F$ acute respiratory failure, ICU intensive care unit, $P E E P$ positive end-expiratory pressure, BiPAP bilevel positive airway pressure, SBT spontaneous breathing trail, CPAP continuous positive airway pressure, $P a O 2$ partial pressure of oxygen, $A H R I$ acute hypoxemic respiratory insufficiency, $\mathrm{mm}$ millimeter, $\mathrm{Hg}$ mercury, $T V$ tidal volume, $P S$ pressure support 
Table 2 Baseline demographic and clinical characteristics of included patients

\begin{tabular}{|c|c|c|c|c|c|c|c|c|c|}
\hline Study name & $\begin{array}{l}\text { Study } \\
\text { groups }\end{array}$ & $\begin{array}{l}\text { Total } \\
\text { number }\end{array}$ & Age & $\begin{array}{l}\text { Male } \\
(\%)\end{array}$ & BMI & SAPS II score & $\begin{array}{l}\text { Respiratory } \\
\text { rate }\end{array}$ & $\begin{array}{l}\mathrm{PaO} 2 / \mathrm{FiO} 2 \\
\text { ratio }\end{array}$ & $\mathrm{PaCO} 2$ \\
\hline \multirow[t]{2}{*}{ Yu 2017} & HFNC & 56 & $56.31 \pm 7.03$ & 54 & $26.32 \pm 4.73$ & NA & $18.43 \pm 3.45$ & $350 \pm 33.87$ & $41.73 \pm 6.33$ \\
\hline & SO & 54 & $55.82 \pm 7.92$ & 52 & $25.19 \pm 5.02$ & NA & $17.98 \pm 3.87$ & $341 \pm 40.65$ & $43.52 \pm 4.93$ \\
\hline \multirow[t]{2}{*}{ Jaber 2016} & NIV & 148 & $62.5 \pm 14.5$ & 78.4 & $27.2 \pm 5.9$ & $33.6 \pm 12.8$ & $28.2+7.7$ & $201 \pm 69$ & $39 \pm 7$ \\
\hline & $\mathrm{SO}$ & 145 & $64.4 \pm 13.1$ & 74.5 & $27.1 \pm 6.2$ & $33.4 \pm 11.7$ & $28.8+7.3$ & $188 \pm 71$ & $37 \pm 7$ \\
\hline \multirow[t]{2}{*}{ Gupta 2016} & HFNC & 10 & NA & NA & NA & NA & NA & NA & NA \\
\hline & NIV & 10 & NA & NA & NA & NA & NA & NA & NA \\
\hline \multirow[t]{2}{*}{ Futier 2016} & HFNC & 108 & $62 \pm 12$ & 56 & $25 \pm 4$ & NA & NA & NA & NA \\
\hline & SO & 112 & $61 \pm 13$ & 57 & $25 \pm 4$ & NA & NA & NA & NA \\
\hline \multirow[t]{2}{*}{ Stephan 2015} & NIV & 416 & $\begin{array}{l}63.9(62.6- \\
65.2)\end{array}$ & 67 & $\begin{array}{l}28.2(27.6- \\
28.7)\end{array}$ & $\begin{array}{l}28.8(27.7- \\
30.0)\end{array}$ & $\begin{array}{l}23.2(22.6- \\
24.0)\end{array}$ & $203(195-212)$ & $\begin{array}{l}39.1(38.4- \\
39.8)\end{array}$ \\
\hline & HFNC & 414 & $\begin{array}{l}63.8(62.5- \\
65.2)\end{array}$ & 66 & $\begin{array}{l}28.3(27.8- \\
28.8)\end{array}$ & $\begin{array}{l}29.0(27.8- \\
30.1)\end{array}$ & $\begin{array}{l}22.8(22.1- \\
23.5)\end{array}$ & $196(187-204)$ & $\begin{array}{l}38.7(38.1- \\
39.4)\end{array}$ \\
\hline \multirow[t]{2}{*}{ Zhu 2013} & NIV & 48 & $62 \pm 10.3$ & 66 & $25.3 \pm 4.6$ & NA & $28.3 \pm 8.6$ & NA & $38.9 \pm 12.2$ \\
\hline & $\mathrm{SO}$ & 47 & $61 \pm 12.2$ & 57 & $24.4 \pm 3.5$ & NA & $25.4 \pm 6.7$ & NA & $38.3 \pm 11.3$ \\
\hline \multirow{2}{*}{$\begin{array}{l}\text { Squadrone } \\
2005\end{array}$} & NIV & 105 & $66 \pm 9$ & 68 & $26.5 \pm 4.7$ & $27 \pm 7$ & NA & $247 \pm 33$ & $39 \pm 7$ \\
\hline & $\mathrm{SO}$ & 104 & $65 \pm 10$ & 62 & $26.3 \pm 4.5$ & $28 \pm 8$ & & $255 \pm 31$ & $39 \pm 5$ \\
\hline \multirow[t]{2}{*}{ Aurian 2001} & NIV & 24 & $58.9 \pm 10$ & NA & NA & $16.9 \pm 5.4$ & $26.25 \pm 13.2$ & $124 \pm 50.2$ & $63.9 \pm 20.5$ \\
\hline & $\mathrm{SO}$ & 24 & $63 \pm 9$ & NA & NA & $16.8 \pm 4.4$ & $29.5 \pm 6.9$ & $111 \pm 54.3$ & $43.4 \pm 9.3$ \\
\hline \multirow{2}{*}{$\begin{array}{l}\text { Antonelle } \\
2000\end{array}$} & NIV & 20 & $45 \pm 19$ & 65 & NA & NA & $38 \pm 3$ & NA & $42 \pm 10$ \\
\hline & SO & 20 & $44 \pm 10$ & 60 & NA & NA & $37 \pm 1$ & NA & $38 \pm 10$ \\
\hline
\end{tabular}

Data are provided percent (\%), mean $\pm \mathrm{SD}$, or median (interquartile range)

HFNC high-flow nasal cannula, SO standard oxygen, NIV non-invasive ventilation, BMI body mass index, SAPS simplified acute physiology score, PaO2/FiO2 partial pressure of arterial oxygen to fraction of inspired oxygen ratio, $\mathrm{PaCO} 2$ partial pressure of arterial carbon dioxide, NA not available

factors play a role in the development of post-operative respiratory failure, including diaphragmatic dysfunction, retained secretions, and atelectasis and alveolar collapse which promote bacterial growth and infections [27-29]. Non-invasive ventilation (NIV) improves oxygenation by recruiting collapsed alveoli and increasing tidal volume participating in gas exchange without hemodynamic adverse events $[1,30]$. However, previous studies and meta-analyses had not shown a significant reduction in intubation rates with prophylactic use of NIV after surgery, despite the reduction in the incidence of postoperative pulmonary complications [31-33].

Currently, NIV is recommended in the treatment of patients with post-operative respiratory failure according to the ERS/ATS guidelines [15]. Our results indicate that intubation rates and mortality are significantly lower in patient populations who are at an increased risk or have developed postoperative respiratory failure treated with NIV in comparison with standard oxygen. In our subgroup analysis, mortality benefit was only noted in patients undergoing cardiothoracic surgeries but not in abdominal surgeries. In an RCT examining NIV vs standard oxygen therapy in patients with respiratory failure after abdominal surgeries, Jaber and Antonelli found that NIV was associated with lower intubation rates, less days on mechanical ventilator, and significantly lower rates of healthcare-associated infections, including pneumonia. Although mortality rates were lower in the NIV group (14 vs $21 \%$ ), the difference did not reach a statistical significance in their study [22]. Similarly, patients undergoing cardiothoracic surgery and treated with NIV for postoperative respiratory failure had lower rates of intubation and mortality when compared to patients treated with standard oxygen therapy [19, 24].

HFNC is a new oxygenation strategy that has been used more frequently in patients with respiratory failure. It is found to be more comfortable than NIV and can deliver concentrated oxygen reaching $100 \%$ with a high flow rate up to $60 \mathrm{~mL} / \mathrm{min}[34,35]$. Furthermore, it can provide positive end-expiratory pressure up to 2$3 \mathrm{mmHG}[34,35]$. The use of HFNC has shown beneficial effects in patients who developed post-extubation respiratory failure or when used during intubation to prevent hypoxemia when compared to standard oxygen [36-38]. Additionally, Frat et al. found lower mortality rates with HFNC in comparison with NIV and conventional oxygen in patients with non-hypercapnic hypoxemic respiratory failure. However, other trials did not find differences between HFNC and standard oxygen therapy [39-42]. The use of HFNC in the post-operative 


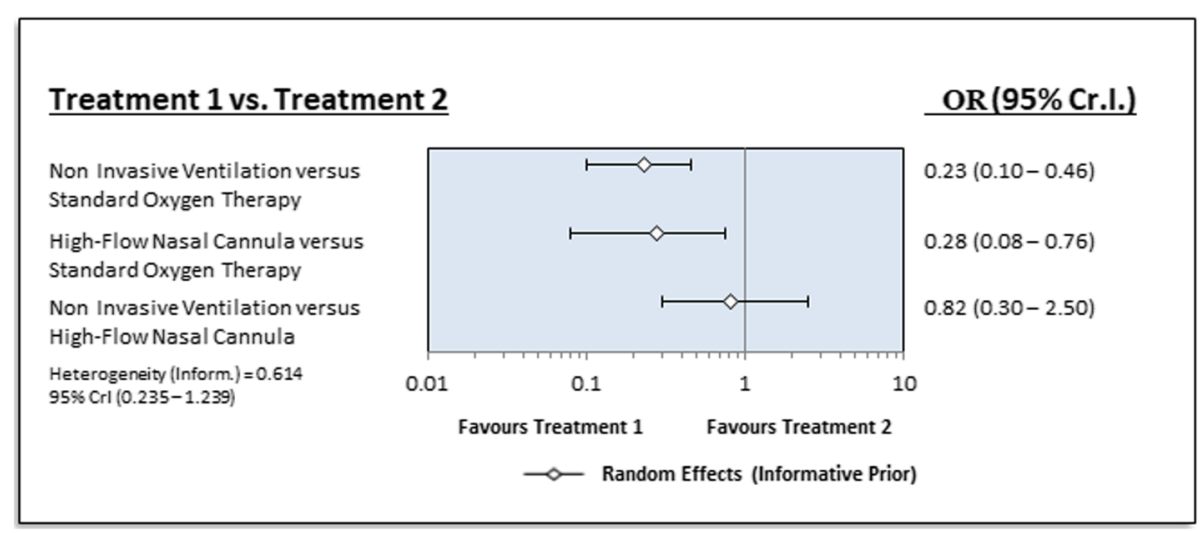

Fig. 2 Forest plot for the rate of intubation between competing interventions

period was investigated by several RCTs. In a large RCT involving more than 800 patients after cardiac surgery, the use of HFNC and NIV in the treatment of high-risk patients or those who had developed post-operative respiratory failure was similar between both interventions with similar intubation rates, mortality, and rates of hospital-acquired infections [20]. In our analysis, there was no difference between HFNC and NIV in intubation rates, mortality, and ICU-acquired infections. Similar results were also found in both subgroups (cardiothoracic surgeries and abdominal surgeries).

In addition, HFNC was associated with lower intubation rates in patients following cardiothoracic surgeries but not following abdominal surgeries when compared to standard oxygen therapy. This could be explained by the fact that in thoracic surgery, HFNC could minimize lung decruitment post-extubation by providing some level of continuous positive airway pressure through

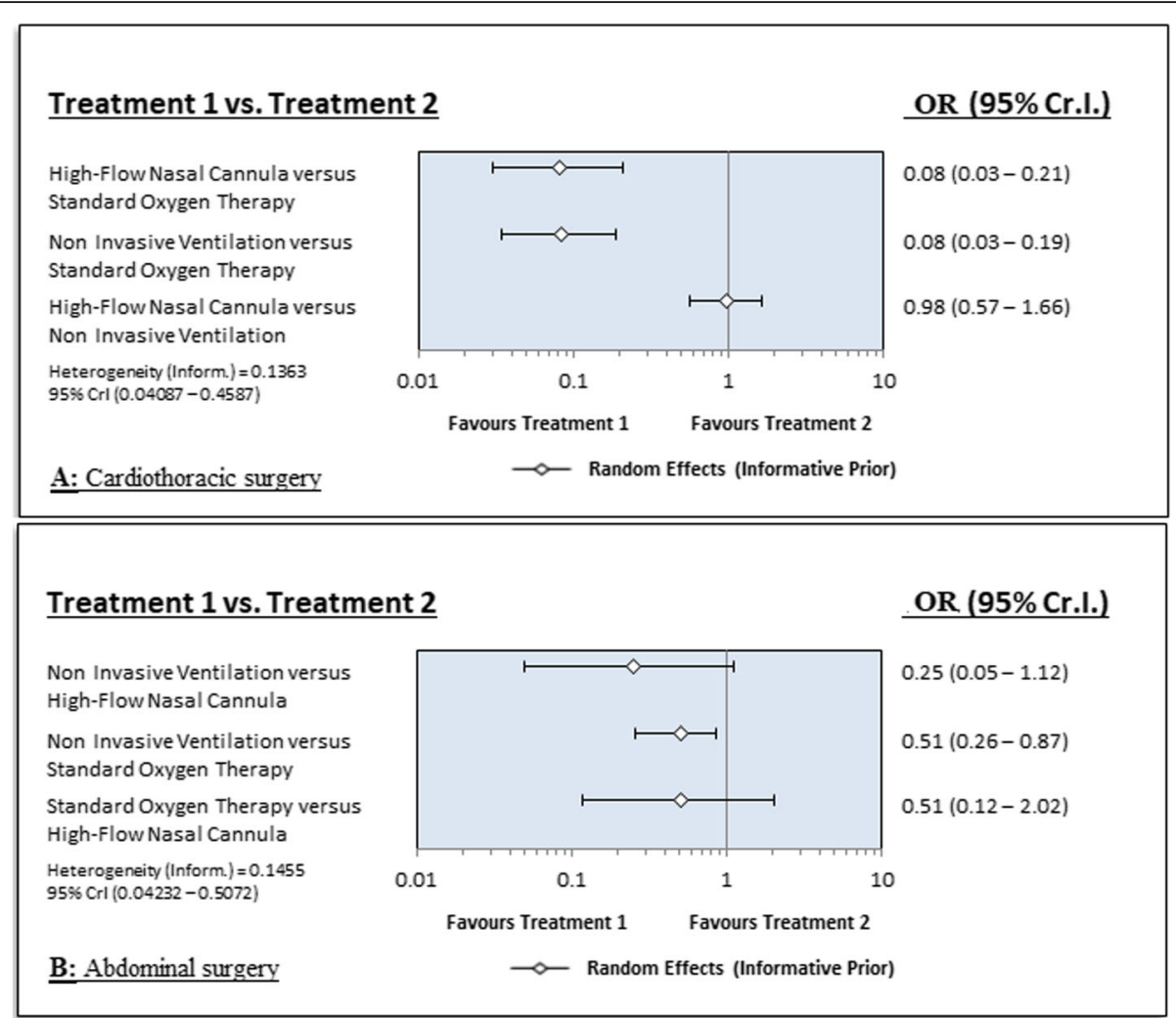

Fig. 3 Forest plot for the rate of intubation between competing interventions following cardiothoracic surgery (a) and abdominal (b) surgery 
Treatment 1 vs. Treatment 2

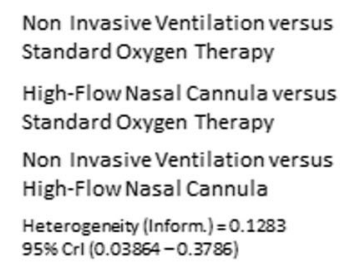
$95 \% \mathrm{Crl}(0.03864-0.3786)$

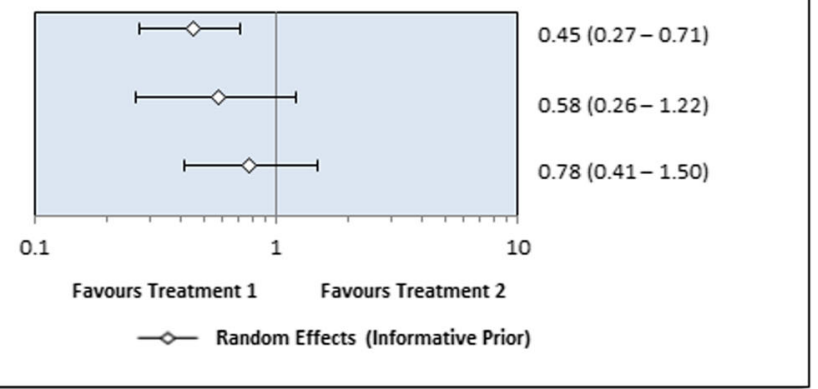

OR (95\% Cr.I.)

$0.45(0.27-0.71)$

$0.58(0.26-1.22)$

$0.78(0.41-1.50)$

Fig. 4 Forest plot for mortality between competing interventions

high-flow ventilation, though this positive pressure can be variable due to the leak around the nasal cannula and nonguaranteed closed mouth of the patients [26].

Furthermore, we found lower rates of infections with HFNC and NIV when compared to standard oxygen are attributed to lower intubation rates in both interventions, which avoids the need for mechanical ventilation and decreases catheter-associated infections.
Although there was no significant difference between HFNC and NIV with regard to rates of intubation, mortality, and ICU-associated infections, when each of these two strategies was compared to standard oxygen, NIV was associated with a survival benefit especially in patients who had cardiothoracic surgery. Additionally, there was a trend toward lower mortality in abdominal surgeries, but HFNC had no mortality benefit in the
Treatment 1 vs. Treatment 2

Non Invasive Ventilation versus Standard Oxygen Therapy High-Flow Nasal Cannula versus Standard Oxygen Therapy Non Invasive Ventilation versus High-Flow Nasal Cannula Heterogeneity (Inform.) $=0.1299$ $95 \% \mathrm{Crl}(0.03987-0.3979)$

A: Cardiothoracic surgery

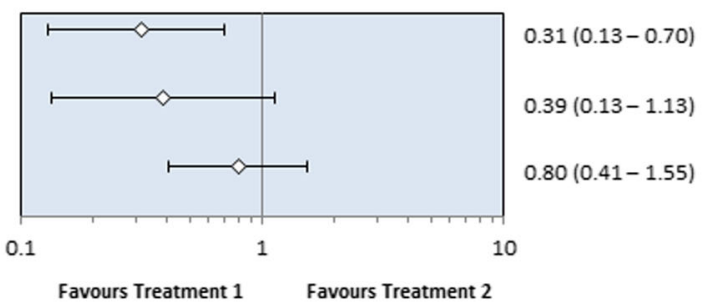

$\multimap$ Random Effects (Informative Prior)

\section{OR (95\% Cr.I.)}

$0.31(0.13-0.70)$

$0.80(0.41-1.55)$

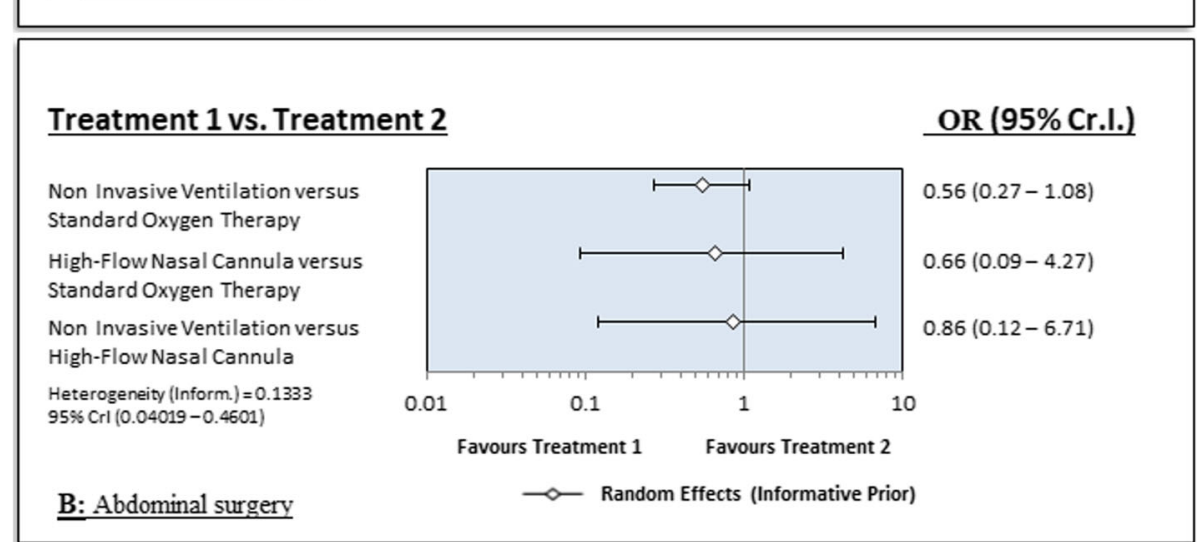

Fig. 5 Forest plot for mortality between competing interventions following cardiothoracic surgery (a) and abdominal surgery (b) 


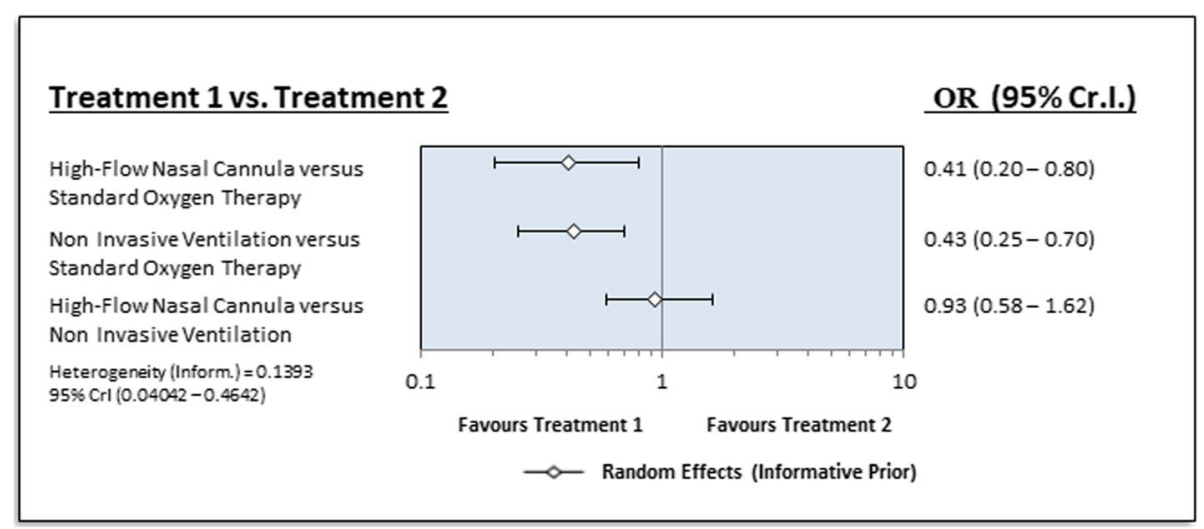

Fig. 6 Forest plot for the incidence of ICU-acquired infections between competing interventions

total patient population and both subgroups. Whether a lower number of patients included in the comparison between HFNC and standard oxygen or certain other factors could have contributed to the inability to detect a mortality benefit despite a significant reduction of intubation rates is needed to be addressed in further larger and well-controlled trials.

Nevertheless, due to the low events, further RCTs are needed to compare between both interventions in different types of surgeries to determine its effect on various long-term clinical outcomes and quality of life and also to examine whether certain patients' risk factors could affect the beneficial effects of these interventions towards reduction of intubation rates and mortality.

\section{Limitations}

Our analysis has several limitations. First, we were unable to perform analysis based on various risk factors, duration of surgery, severity scores, and different surgical types as we lack patients' level data. Second, blinding of intervention and personnel was impossible given the nature of intervention. Third, there were few sample size and limited events, and therefore, larger trials and longterm outcomes are needed. Fourth, we used informative prior module for our analysis which could affect the results given the small number of included trials. Fifth, there was a significant time gap between included studies through which there was a significant development in the ICU management, preoperative and postoperative evaluation and care, supportive management, and criteria for admission to the ICU.

\section{Conclusion}

Among patients who are at risk for developing postoperative respiratory failure, or have developed postoperative respiratory failure, the use of NIV was associated with reduced rates of intubation, mortality, and ICU-acquired infections in comparison with standard oxygen therapy. In addition, HFNC was associated with reduced rates of intubation and ICU-acquired infections but not mortality in comparison with standard oxygen. There was no significant difference between HFNC and NIV on the various studied clinical outcomes.

\section{Supplementary information}

Supplementary information accompanies this paper at https://doi.org/10. 1186/s40560-020-00468-X.

\section{Supplementary figure 1:. Network geometry. Number of participants in each group represented with node size and the edge widths are proportional to the number of studies between different interventions. A = High-flow nasal cannula; $B=$ Non-invasive ventilation; $C=$ standard oxygen therapy. \\ Supplementary figure 2:. Risk of bias assessment based on authors' judgment for each of the included RCTs. Blank items indicate unclear risk of bias. \\ Supplementary figure 3: Regression of $\mathrm{PaCO} 2$ on intubation rate between non-invasive ventilation and standard oxygen. Higher $\mathrm{PaCO} 2$ was associated with a lower risk for intubation with NIV use $(P<0.05)$. \\ Supplementary figure 4:. Direct meta-analysis results between NIV ver- sus standard oxygen showing forest plots for intubation rate, mortality, and ICU acquired infections. \\ Supplementary figure 5:. Results of individual studies comparing between HFNC and standard oxygen for different outcomes. \\ Supplementary figure 6:. Results of individual studies comparing between NIV and HFNC for different outcomes.}

\section{Abbreviations}

NIV: Non-invasive ventilation; HFNC: High-flow nasal cannula; ICU: Intensive care unit; RCT: Randomized controlled trial; OR: Odds ratio; Cr.l.: Credible interval

\section{Acknowledgements}

NA

\section{Authors' contributions}

Y.Z:: study design, literature search, data analysis, data extraction, drafting the manuscript, final approval of the manuscript.

B.K.: study design, data analysis, drafting the manuscript, final approval of the manuscript. M.B.: literature search, drafting the manuscript, final approval of the manuscript. L.R.: data extraction, drafting the manuscript, final approval of the manuscript. I.G.: literature search, drafting the manuscript, final approval of the manuscript. E.l.: study design, data analysis, literature search, 
drafting the manuscript, final approval of the manuscript. J.K.: literature search, drafting the manuscript, final approval of the manuscript. F.R.: drafting the manuscript, final approval of the manuscript. S.S.: data extraction, drafting the manuscript, final approval of the manuscript. A.B.: data analysis, drafting the manuscript, final approval of the manuscript. S.Se.: data extraction, drafting the manuscript, final approval of the manuscript. G.B.: drafting the manuscript, final approval of the manuscript. E.S.: study design, drafting the manuscript, final approval of the manuscript. The authors read and approved the final manuscript.

\section{Funding}

There was no funding for this work.

\section{Availability of data and materials}

Data and materials are available and can be presented upon request.

\section{Ethics approval and consent to participate} NA

\section{Consent for publication}

The authors give the Journal of Intensive Care the consent for publishing this manuscript. There are no personal information that required consent

\section{Competing interests}

The authors have no competing interests to declare.

\section{Author details}

'Department of Internal Medicine, Hurley Medical Center/Michigan State University, One Hurley Plaza, Suite 212, Flint, MI 48503, USA. ${ }^{2}$ Knight Cardiovascular Institute, Oregon Health \& Science University, Portland, Oregon, USA. ${ }^{3}$ College of Human Medicine, Michigan State University, East Lansing, MI, USA. ${ }^{4}$ Department of Anesthesia, Lebanese University, Beirut, Lebanon. ${ }^{5}$ College of Osteopathic Medicine, Michigan State University, East Lansing, MI, USA. ${ }^{6}$ Department of Pulmonary and Critical Care, Hurley Medical Center/Michigan State University, Flint, MI, USA.

\section{Received: 3 April 2020 Accepted: 8 July 2020}

\section{Published online: 17 July 2020}

\section{References}

1. Chiumello D, Chevallard G, Gregoretti C. Non-invasive ventilation in postoperative patients: a systematic review. Intensive Care Med [Internet]. 2011;37:918-29 Available from: http://www.ncbi.nlm.nih.gov/ pubmed/21424246.

2. Pearse RM, Moreno RP, Bauer P, Pelosi P, Metnitz P, Spies C, et al. Mortality after surgery in Europe: a 7 day cohort study. Lancet (London, England) [Internet]. 2012;380:1059-65 Available from: http://www.ncbi.nlm.nih.gov/ pubmed/22998715.

3. Serpa Neto A, Hemmes SNT, Barbas CSV, Beiderlinden M, FernandezBustamante A, Futier E, et al. Incidence of mortality and morbidity related to postoperative lung injury in patients who have undergone abdominal or thoracic surgery: a systematic review and meta-analysis. Lancet Respir Med [Internet]. 2014;2:1007-15 Available from: http://www.ncbi.nlm.nih.gov/ pubmed/25466352.

4. Canet J, Gallart L, Gomar C, Paluzie G, Vallès J, Castillo J, et al. Prediction of postoperative pulmonary complications in a population-based surgical cohort. Anesthesiology [Internet]. 2010;113:1338-50 Available from: http:// www.ncbi.nlm.nih.gov/pubmed/21045639.

5. Mazo V, Sabaté S, Canet J, Gallart L, de Abreu MG, Belda J, et al. Prospective external validation of a predictive score for postoperative pulmonary complications. Anesthesiology [Internet]. 2014;121:219-31 Available from: http://www.ncbi.nlm.nih.gov/pubmed/24901240.

6. Gallart L, Canet J. Post-operative pulmonary complications: Understanding definitions and risk assessment. Best Pract Res Clin Anaesthesiol [Internet]. 2015;29:315-30. Available from. http://www.ncbi.nlm.nih.gov/ pubmed/26643097.

7. Arozullah AM, Khuri SF, Henderson WG, Daley J. Participants in the National Veterans Affairs Surgical Quality Improvement Program. Development and validation of a multifactorial risk index for predicting postoperative pneumonia after major noncardiac surgery. Ann Intern Med [Internet]. 2001; 135:847-57 Available from: http://www.ncbinlm.nih.gov/pubmed/11712875.
8. Futier E, Constantin J-M, Paugam-Burtz C, Pascal J, Eurin M, Neuschwander A, et al. A trial of intraoperative low-tidal-volume ventilation in abdominal surgery. N Engl J Med [Internet]. 2013;369:428-37 Available from: http:// www.ncbi.nlm.nih.gov/pubmed/23902482.

9. Canet J, Gallart L. Postoperative respiratory failure: pathogenesis, prediction, and prevention. Curr Opin Crit Care [Internet]. 2014;20:56-62 Available from: http://www.ncbi.nlm.nih.gov/pubmed/24240985.

10. Brochard L, Mancebo J, Wysocki M, Lofaso F, Conti G, Rauss A, et al. Noninvasive ventilation for acute exacerbations of chronic obstructive pulmonary disease. N Engl J Med [Internet]. 1995;333:817-22 Available from: http://www.ncbi.nlm.nih.gov/pubmed/7651472.

11. Keenan SP, Sinuff T, Cook DJ, Hill NS. Which patients with acute exacerbation of chronic obstructive pulmonary disease benefit from noninvasive positive-pressure ventilation? A systematic review of the literature. Ann Intern Med [Internet]. 2003;138:861-70 Available from: http:// www.ncbi.nlm.nih.gov/pubmed/12779296.

12. Lightowler JV, Wedzicha JA, Elliott MW, Ram FSF. Non-invasive positive pressure ventilation to treat respiratory failure resulting from exacerbations of chronic obstructive pulmonary disease: Cochrane systematic review and meta-analysis. BMJ [Internet]. 2003;326:185 Available from: http://www.ncbi. nlm.nih.gov/pubmed/12543832.

13. Frat J-P, Coudroy R, Thille AW. Non-invasive ventilation or high-flow oxygen therapy: when to choose one over the other? Theatr Res Int. 2018; Available from: http://www.ncbi.nlm.nih.gov/pubmed/30406954.

14. Parke $R$, McGuinness S, Dixon R, Jull A. Open-label, phase II study of routine high-flow nasal oxygen therapy in cardiac surgical patients. Br J Anaesth [Internet]. 2013;111:925-31 Available from: http://www.ncbi.nlm.nih.gov/ pubmed/23921199.

15. Rochwerg B, Brochard L, Elliott MW, Hess D, Hill NS, Nava S, et al. Official ERS/ATS clinical practice guidelines: noninvasive ventilation for acute respiratory failure. Eur Respir J [Internet], Available from. 2017;50 http:// www.ncbi.nlm.nih.gov/pubmed/28860265

16. Moher D, Shamseer L, Clarke M, Ghersi D, Liberati A, Petticrew M, et al. Preferred reporting items for systematic review and meta-analysis protocols (PRISMA-P) 2015 statement. Syst Rev [Internet]. 2015;4:1 Available from: http://www.ncbi.nlm.nih.gov/pubmed/25554246.

17. Higgins JPT, Altman DG, Gøtzsche PC, Jüni P, Moher D, Oxman AD, et al. The Cochrane Collaboration's tool for assessing risk of bias in randomised trials. BMJ [Internet]. 2011;343:d5928 Available from: http://www.ncbi.nlm. nih.gov/pubmed/22008217.

18. Gupta S, Govil D, Srinivasan S, Patel SJ, Gupta A, Tomar DS, et al. High flow nasal cannula (HFNC) as an alternative to noninvasive ventilation (NIV) in acute respiratory failure (ARF) in immunosuppressed patients-an Indian post liver transplant experience. Intensive Care Med Exp Conf 29th Annu Congr Eur Soc intensive care Med ESICM 2016 Italy [Internet]. 2016;4 Available from: https://www.cochranelibrary.com/central/doi/10.1002/central/CN01407482/full.

19. Zhu G, Wang D, Liu S, Jia M, Jia S. Efficacy and safety of noninvasive positive pressure ventilation in the treatment of acute respiratory failure after cardiac surgery. Chin Med J (Engl) [Internet]. 2013;126:4463-9 Available from: http://www.ncbi.nlm.nih.gov/pubmed/24286408.

20. Stéphan F, Barrucand B, Petit P, Rézaiguia-Delclaux S, Médard A, Delannoy B, et al. High-flow nasal oxygen vs noninvasive positive airway pressure in hypoxemic patients after cardiothoracic surgery: a randomized clinical trial. JAMA [Internet]. 2015;313:2331-9 Available from: http://www.ncbi.nlm.nih. gov/pubmed/25980660.

21. Squadrone V, Coha M, Cerutti E, Schellino MM, Biolino P, Occella P, et al. Continuous positive airway pressure for treatment of postoperative hypoxemia: a randomized controlled trial. JAMA [Internet]. 2005;293:589-95 Available from: http://www.ncbi.nlm.nih.gov/pubmed/15687314.

22. Jaber $S$, Lescot $T$, Futier E, Paugam-Burtz C, Seguin P, Ferrandiere M, et al. Effect of noninvasive ventilation on tracheal reintubation among patients with hypoxemic respiratory failure following abdominal surgery: a randomized clinical trial. JAMA [Internet]. 2016:315:1345-53 Available from: http://www.ncbi.n/m.nih.gov/pubmed/26975890.

23. Futier E, Paugam-Burtz C, Godet T, Khoy-Ear L, Rozencwajg S, Delay J-M, et al. Effect of early postextubation high-flow nasal cannula vs conventional oxygen therapy on hypoxaemia in patients after major abdominal surgery: a French multicentre randomised controlled trial (OPERA). Intensive Care Med [Internet]. 2016;42:1888-98 Available from: http://www.ncbi.nlm.nih.gov/ pubmed/27771739. 
24. Auriant I, Jallot A, Hervé P, Cerrina J, Le Roy LF, Fournier $J$, et al. Noninvasive ventilation reduces mortality in acute respiratory failure following lung resection. Am J Respir Crit Care Med [Internet]. 2001;164: 1231-5 Available from: http://www.ncbi.nlm.nih.gov/pubmed/11673215.

25. Antonelli M, Conti G, Bufi M, Costa MG, Lappa A, Rocco M, et al. Noninvasive ventilation for treatment of acute respiratory failure in patients undergoing solid organ transplantation: a randomized trial. JAMA [Internet]. 2000;283:235-41 Available from: http://www.ncbi.nlm.nih.gov/pubmed/1 0634340.

26. Yu Y, Qian X, Liu C, Zhu C. Effect of high-flow nasal cannula versus conventional oxygen therapy for patients with thoracoscopic lobectomy after extubation. Can Respir J [Internet]. 2017;2017:7894631 Available from: http://www.ncbi.nlm.nih.gov/pubmed/28298878.

27. Ahmed AA. Dysfunction of the diaphragm. N Engl J Med [Internet]. 2012; 366:2036-7 author reply 2037. Available from: http://www.ncbi.nlm.nih.gov/ pubmed/22621640.

28. Canet J, Mazo V. Postoperative pulmonary complications. Minerva Anestesiol [Internet]. 2010;76:138-43 Available from: http://www.ncbi.nlm. nih.gov/pubmed/20150855.

29. van Kaam AH, Lachmann RA, Herting E, De Jaegere A, van Iwaarden F, Noorduyn $L A$, et al. Reducing atelectasis attenuates bacterial growth and translocation in experimental pneumonia. Am J Respir Crit Care Med [Internet]. 2004;169:1046-53 Available from: http://www.ncbi.nlm.nih.gov/ pubmed/14977624.

30. Jaber S, Antonelli M. Preventive or curative postoperative noninvasive ventilation after thoracic surgery: still a grey zone? Intensive Care Med [Internet]. 2014;40:280-3 Available from: http://www.ncbi.nlm.nih.gov/ pubmed/24445592.

31. Zarbock A, Mueller E, Netzer S, Gabriel A, Feindt P, Kindgen-Milles D. Prophylactic nasal continuous positive airway pressure following cardiac surgery protects from postoperative pulmonary complications: a prospective, randomized, controlled trial in 500 patients. Chest [Internet] 2009;135:1252-9 Available from: http://www.ncbi.n/m.nih.gov/pubmed/1901 7864.

32. Al Jaaly E, Fiorentino F, Reeves BC, Ind PW, Angelini GD, Kemp S, et al. Effect of adding postoperative noninvasive ventilation to usual care to prevent pulmonary complications in patients undergoing coronary artery bypass grafting: a randomized controlled trial. J Thorac Cardiovasc Surg [Internet]. 2013;146:912-8 Available from: http://www.ncbi.nlm.nih.gov/pubmed/23582 830.

33. Ireland CJ, Chapman TM, Mathew SF, Herbison GP, Zacharias M. Continuous positive airway pressure (CPAP) during the postoperative period for prevention of postoperative morbidity and mortality following major abdominal surgery. Cochrane database Syst Rev [Internet]. 2014:CD008930 Available from: http://www.ncbi.nlm.nih.gov/pubmed/25081420.

34. Mauri T, Turrini C, Eronia N, Grasselli G, Volta CA, Bellani G, et al. Physiologic effects of high-flow nasal cannula in acute hypoxemic respiratory failure. Am J Respir Crit Care Med [Internet]. 2017;195:1207-15 Available from: http://www.ncbi.nlm.nih.gov/pubmed/27997805.

35. Corley A, Caruana LR, Barnett AG, Tronstad O, Fraser JF. Oxygen delivery through high-flow nasal cannulae increase end-expiratory lung volume and reduce respiratory rate in post-cardiac surgical patients. Br J Anaesth [Internet]. 2011;107:998-1004 Available from: http://www.ncbi.nlm.nih.gov/ pubmed/21908497.

36. Maggiore SM, Idone FA, Vaschetto R, Festa R, Cataldo A, Antonicelli F, et al. Nasal high-flow versus Venturi mask oxygen therapy after extubation. Effects on oxygenation, comfort, and clinical outcome. Am J Respir Crit Care Med [Internet]. 2014;190:282-8 Available from: http://www.ncbi.nlm.nih.gov/ pubmed/25003980.

37. Rittayamai N, Tscheikuna J, Rujiwit P. High-flow nasal cannula versus conventional oxygen therapy after endotracheal extubation: a randomized crossover physiologic study. Respir Care [Internet]. 2014;59:485-90 Available from: http://www.ncbi.n/m.nih.gov/pubmed/24046462.

38. Hernández G, Vaquero C, González P, Subira C, Frutos-Vivar F, Rialp G, et al. Effect of postextubation high-flow nasal cannula vs conventional oxygen therapy on reintubation in low-risk patients: a randomized clinical trial. JAMA [Internet]. 2016;315:1354-61 Available from: http://www.ncbi.nlm.nih. gov/pubmed/26975498.

39. Frat J-P, Thille AW, Mercat A, Girault C, Ragot S, Perbet S, et al. High-flow oxygen through nasal cannula in acute hypoxemic respiratory failure. $\mathrm{N}$
Engl J Med [Internet]. 2015;372:2185-96 Available from: http://www.ncbi. nlm.nih.gov/pubmed/25981908.

40. Lemiale V, Mokart D, Mayaux J, Lambert J, Rabbat A, Demoule A, et al. The effects of a 2-h trial of high-flow oxygen by nasal cannula versus Venturi mask in immunocompromised patients with hypoxemic acute respiratory failure: a multicenter randomized trial. Crit Care [Internet]. 2015;19:380 Available from: http://www.ncbi.nlm.nih.gov/pubmed/26521922.

41. Jones PG, Kamona S, Doran O, Sawtell F, Wilsher M. Randomized controlled trial of humidified high-flow nasal oxygen for acute respiratory distress in the emergency department: the HOT-ER study. Respir Care [Internet]. 2016; 61:291-9 Available from: http://www.ncbi.nlm.nih.gov/pubmed/26577199.

42. Azoulay E, Lemiale V, Mokart D, Nseir S, Argaud L, Pène F, et al. Effect of high-flow nasal oxygen vs standard oxygen on 28-day mortality in immunocompromised patients with acute respiratory failure: the $\mathrm{HIGH}$ randomized clinical trial. JAMA [Internet]. 2018;320:2099-107 Available from: http://www.ncbi.nlm.nih.gov/pubmed/30357270.

\section{Publisher's Note}

Springer Nature remains neutral with regard to jurisdictional claims in published maps and institutional affiliations.
Ready to submit your research? Choose BMC and benefit from:

- fast, convenient online submission

- thorough peer review by experienced researchers in your field

- rapid publication on acceptance

- support for research data, including large and complex data types

- gold Open Access which fosters wider collaboration and increased citations

- maximum visibility for your research: over $100 \mathrm{M}$ website views per year

At BMC, research is always in progress.

Learn more biomedcentral.com/submissions 